\title{
Architettura sacra lungo le sponde del fiume Eufrate. Dura-Europos, il primo edificio di culto cristiano
}

\author{
Francesco Stilo \\ Crystel Mamazza
}

\begin{abstract}
II presente contributo riferisce di un caso studio tra i più emblematici in relazione all'indagine sugli elementi materiali del culto cristiano delle origini, vista da una triplice prospettiva: archeologica, architettonica, iconografica. La chiesa di Dura Europos è ad oggi infatti la più antica architettura, tra le cui mura, già alla prima metà del III secolo, con certezza, si è celebrato il culto cristiano. Una breve introduzione sulla genesi storica della città, apre le porte allo sviluppo di due linguaggi: quello pittorico/iconografico, riferibile ad una rassegna sugli affreschi contenuti nel battistero dell'edificio, e quello morfologico/architettonico, sviluppatosi in operazioni di analisi, ridisegno e modellazione tridimensionale degli elementi architettonici. Lo studio propone una visione sintetica del caso affrontato, focalizzandosi quindi sulla produzione di immagini iconiche che possano dare l'idea della forma dell'edificio al tempo del suo pieno utilizzo. Le ricostruzioni proposte si basano sull'acquisizione e digitalizzazione dei disegni di rilievo prodotti da Henry Pearson e pubblicati in Final ReportVIII, part II. Conservare la memoria di un sito già compromesso ed esposto ad un continuo rischio, e contribuire alla sua conoscenza attraverso il linguaggio del disegno, significa riallacciare, in un momento di grande incertezza e crisi, i rapporti con un passato fragile ed in continuo rischio di oblio, proiettando nel futuro la storia della nostra civiltà.
\end{abstract}

Parole chiave

archeologia, culto, iconografia, Dura-Europos, memoria.

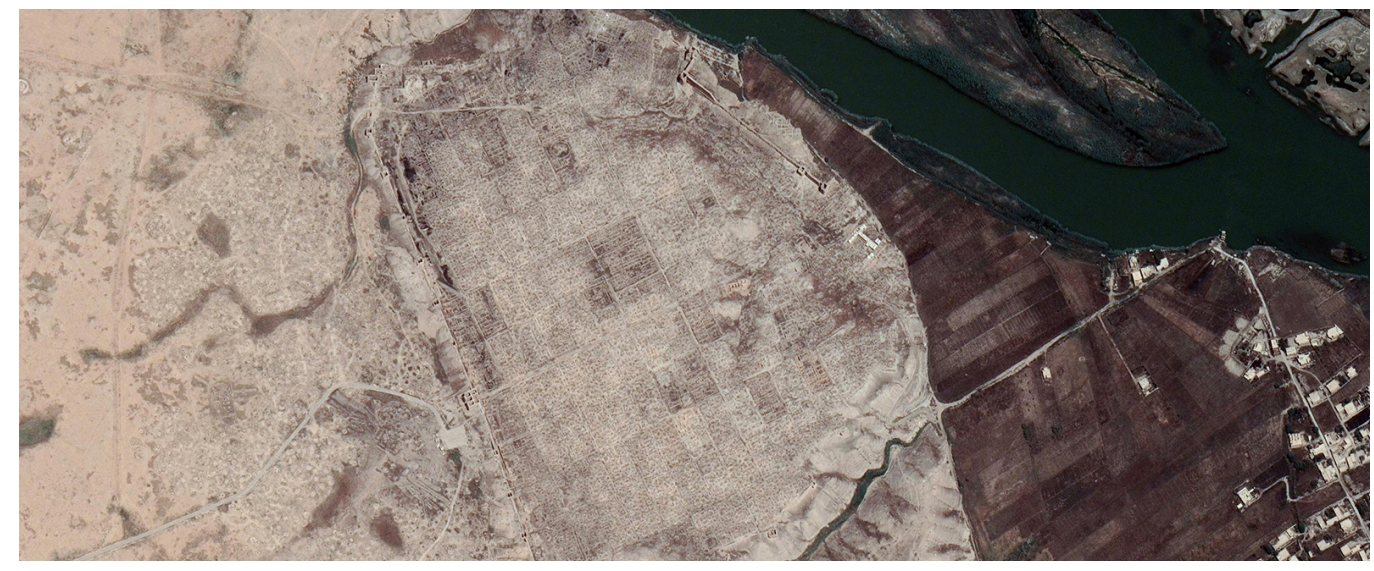




\section{Introduzione}

A rileggere le righe con cui Michael Rostovtzeff descrive il viaggio da lui allora intrapreso per raggiungere le rovine di Dura, si prova una strana nostalgia, per un tempo in cui la ricerca archeologica tra le sabbie del vicino oriente era avventura e rischio. Nel 1928, sebbene il cammello avesse ormai ceduto il passo allo pneumatico dell'automobile, almeno per il viaggiatore occidentale, i percorsi che conducevano a Dura erano ancora incerti e insicuri. II deserto fungeva da immensa ed infida strada, e gruppi di beduini dal temperamento anarchico, si racconta, insidiavano il viaggio, alla ricerca di giovani fanciulle europee da includere nell'harem di qualche sceicco. Tra le vie carovaniere (fig. I) battute ai tempi dei Seleucidi, quelle che conducono da Antiochia sull'Oronte a Seleucia sul Tigri, erano, ad avviso dello storico russo, le più interessanti. Frequentandole, all'epoca del suo scritto, Rostovtzeff descrive un paesaggio in cui la vita appariva "a mala pena mutata dai giorni dei grandi Antiochi, o anche dai tempi babilonesi, ittiti o assiri" [Rostovtzeff 1971, p. I6 I]. Architetture tradizionali, romane, bizantine, punteggiavano indisturbate gli immensi paesaggi, mentre uno sfondo naturale potente, avolgeva lo spazio.

Situata su di un piano roccioso eroso a nord est dal fiume Eufrate, tanto che una porzione della città, ed in particolare la cittadella, di cui rimane ben poco, nel corso dei secoli ne è stata lentamente inghiottita, Dura fu fondata nel IV secolo a.C. dalla dinastia ellenistica dei Seleucidi, per passare poi nel II secolo, sotto il regno dei Parti. La città, a pianta ippodamea (fig. 2, 3), si configurò già nel I secolo a.C. come fortezza di frontiera, luogo multiculturale, coacervo di lingue [I] e di religioni. Conquistata definitivamente dai Romani durante le campagne partiche portate avanti da Lucio Vero I6I-I 66 d.C., la città venne incorporata nella provincia di Syria, rimanendo sotto controllo dell'impero fino alla presa dei Sassanidi di metà III secolo. Dura appariva deserta al tempo in cui Ammiano Marcellino descriveva il luogo come popolato da branchi di cervi [2]. Scoperta nel 1920 da un soldato britannico agli ordini del capitano Murphy, Dura fu oggetto di scavi tra gli anni 20 e 30, condotti da parte di équipes francesi e americane, guidate da F. Cumont prima, ed M. Pillet e C. Hopkins poi [3]. Tra i tanti edifici di culto che affollano la città, particolare interesse ha destato la scoperta di una chiesa pre-basilicale, edificio di ragguardevole importanza, non soltanto perché conferma la presenza di un luogo di culto precostantiniano [4], seppur non realizzato ex novo, ma

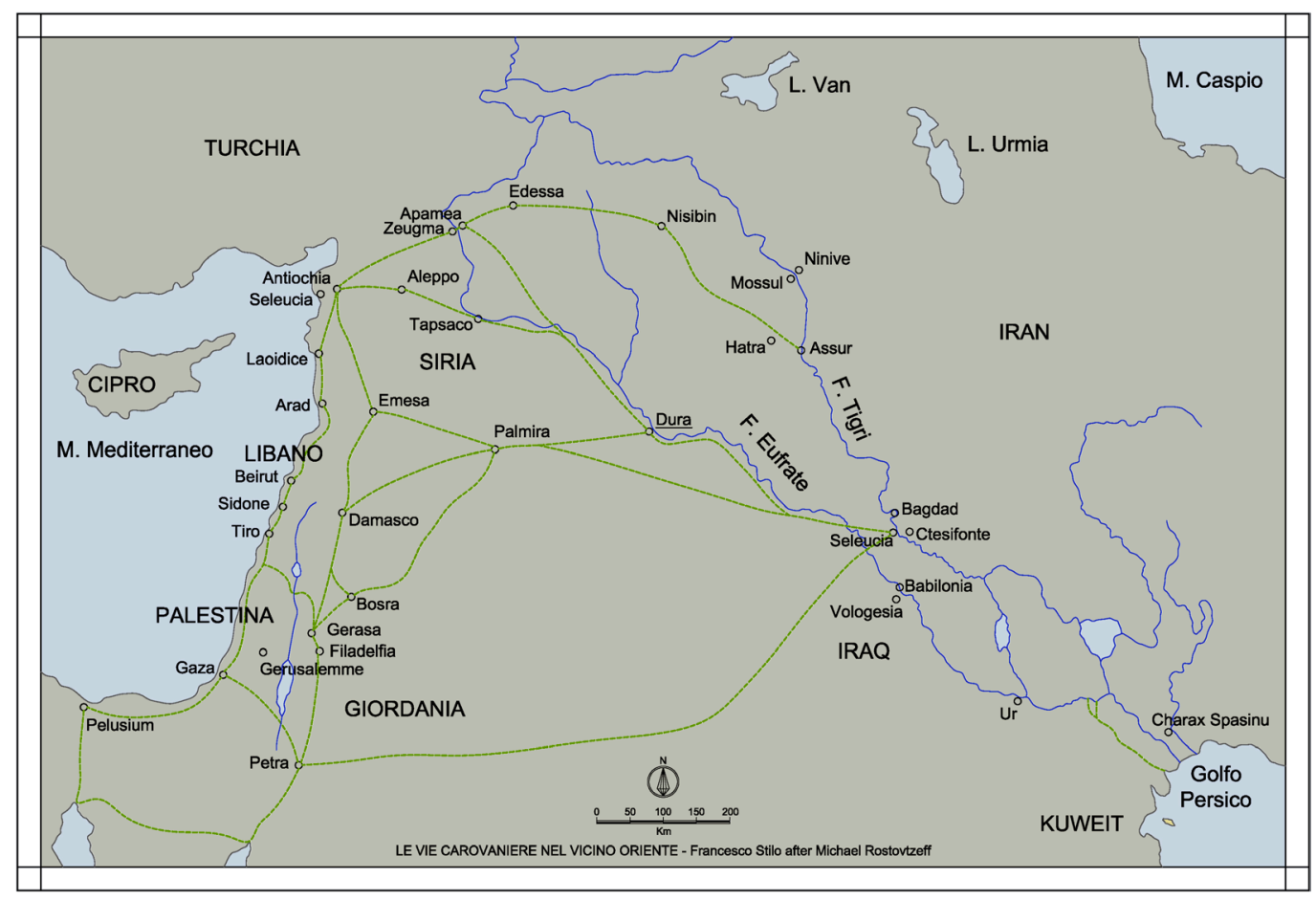




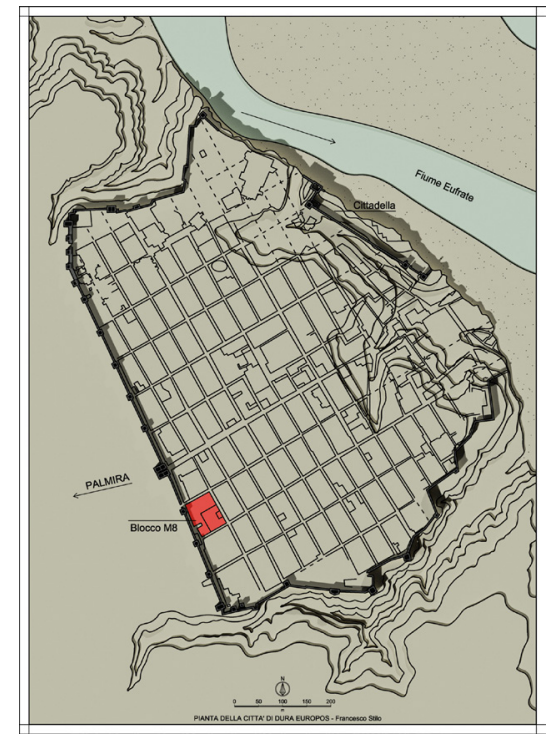

anche perché ci ha lasciato uno dei più importanti e antichi documenti figurativi cristiani. Dal punto di vista dell'architettura l'edificio [5] non mostra l'elaborazione di un linguaggio cristiano [6], ma per quanto riguarda l'apparato pittorico, segna l'incipit di un'arte propriamente cristiana [Bisconti $20 \mathrm{I}$ I, p. 35]. Privilegiato oggetto della discussione è l'ambiente-battistero decorato con pitture tratte dall' Antico e Nuovo Testamento, le quali, dopo diversi restauri, sono oggi conservate presso la Yale Gallery of Fine Arts at New Haven, musealizzate e decontestualizzate perciò dal loro luogo di origine.

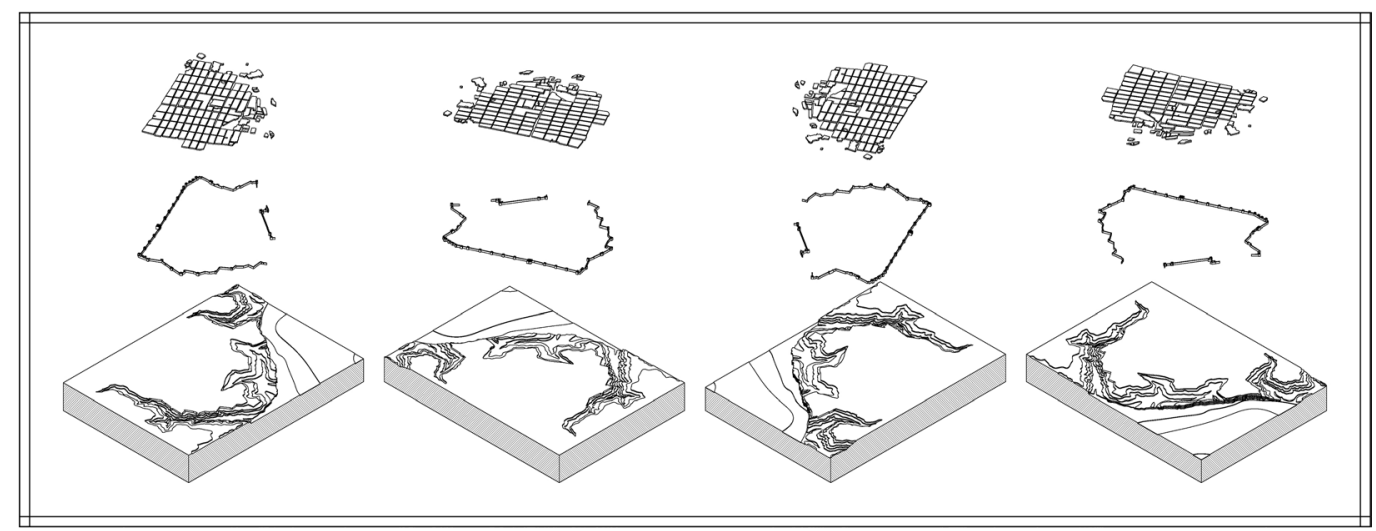

Linguaggio pittorico iconografico

L'ambiente-battistero è caratterizzato dal fonte battesimale nella parete di fondo, introdotto da due colonnine in finto marmo, e da due pareti laterali sulle quali si sviluppano le scene bibliche. Sulla volta della lunetta della parete di fondo, vi è la raffigurazione del cielo stellato, simbolo di illuminazione. Sulla lunetta vi è la raffigurazione di un pastore con il gregge (fig. 4). La figura del pastore è una figura che nella tarda antichità assume significati nuovi che vanno letti in chiave cristiana. Nel momento della risemantizzazione cristiana il pastore diventa simbolo di salvezza [Bisconti 20 I I; Braconi, 20 I2, p. 229], va quindi interpretato come immagine di Cristo che secondo la parabola della pecorella smarrita (Vangelo: Luca (I 5,37), Matteo (I8, I2-14) salva l'anima che si è perduta [Bisconti 2000a, p. 31 I]. C'è quindi un continuum tra cultura figurativa pagana e cristiana. Nel battistero di Dura Europos abbiamo 
la raffigurazione del buon pastore come simbolo della salvezza. In basso a sinistra della lunetta, vi è una immagine poco leggibile, di Adamo ed Eva. I protoparenti, stanti su una linea suolo, sono raffigurati ai lati di un albero con un serpente attorcigliato. Tendenzialmente l'arte cristiana delle origini è un'arte augurale e positiva, sono rari e sporadici i casi in cui si raffigurano scene di passione o di peccato, o in generale scene di violenza [Bisconti 2000b, p. 4l]. Nel caso di Dura Europos la scena dei protoparenti è però necessaria; sono coloro i quali rappresentano la felix culpa, fondamentale per l'attuazione del piano salvifico divino [Bisconti 20 I I, p. 22].

Per quanto riguarda la decorazione delle pareti laterali troviamo nel registro superiore della parete nord (fig. 5) la scena della guarigione del paralitico [7], che incontrerà molta fortuna nell'arte cristiana delle origini. Nella stessa parete, si colloca un episodio assai raro, Pietro salvato dai flutti. Compare in questa scena la figura di Cristo che rappresenta una fonte di salvezza, mentre l'acqua, elemento che ricorre nelle pitture dell'ambiente-battistero, è il mezzo della rigenerazione [Bisconti 20 I2, p. 13], rimandando senz'altro ad un significato battesimale. Nel registro inferiore delle pareti nord ed est vi è la raffigurazione di una megalografia illustrante l'episodio delle pie donne al sepolcro. La scena, che è stata considerata come la più antica rappresentazione della Resurrezione di Cristo [Bisconti, Osservatore Romano 78, 4 aprile 20 I0, p. 4], ben si adatta all'ambiente battistero per il profondo legame che si innesca tra resurrezione ed illuminazione, indicando l'importanza che assumeva per i cristiani la vittoria di Cristo sulla morte [Bisconti 20 I 0, p. 4; Pergola 20 I 0, p. 323]. II concetto di vittoria e trionfo compare anche in un altro episodio collocato sulla parete sud (fig. 6), che vede protagonisti i personaggi di Davide e Golia, i quali alludono al tema della lotta del bene contro il male. Altra scena che decora l'ambiente è quella della samaritana al pozzo. La donna, rappresentata come un personaggio isolato, è raffigurata in primo piano mentre si china per raccogliere l'acqua dal pozzo.

Si può notare come le varie scene neotestamentarie siano legate tra loro da un filo rosso e, come scrive Fabrizio Bisconti, da un leitmotiv fortemente battesimale [Bisconti 2000b, p. 28]. In conclusione si può affermare che questo programma decorativo trova riscontri nel resto dell'orbis christianus antiquus, in particolare nella pittura catacombale romana, mettendo cosi "in contatto poli lontani per geografia e per tipologia monumentale" [Bisconti 20 I4, p. $5 \mathrm{I} 2$. Si possono riscontrare dei caratteri comuni, non solo per quanto riguarda i temi, ma in alcuni casi anche per gli schemi, dimostrando che esiste un "comune denominatore iconografico" [Bisconti 201 I p. 20]. II processo di cristianizzazione tocca quindi luoghi lontani, ma

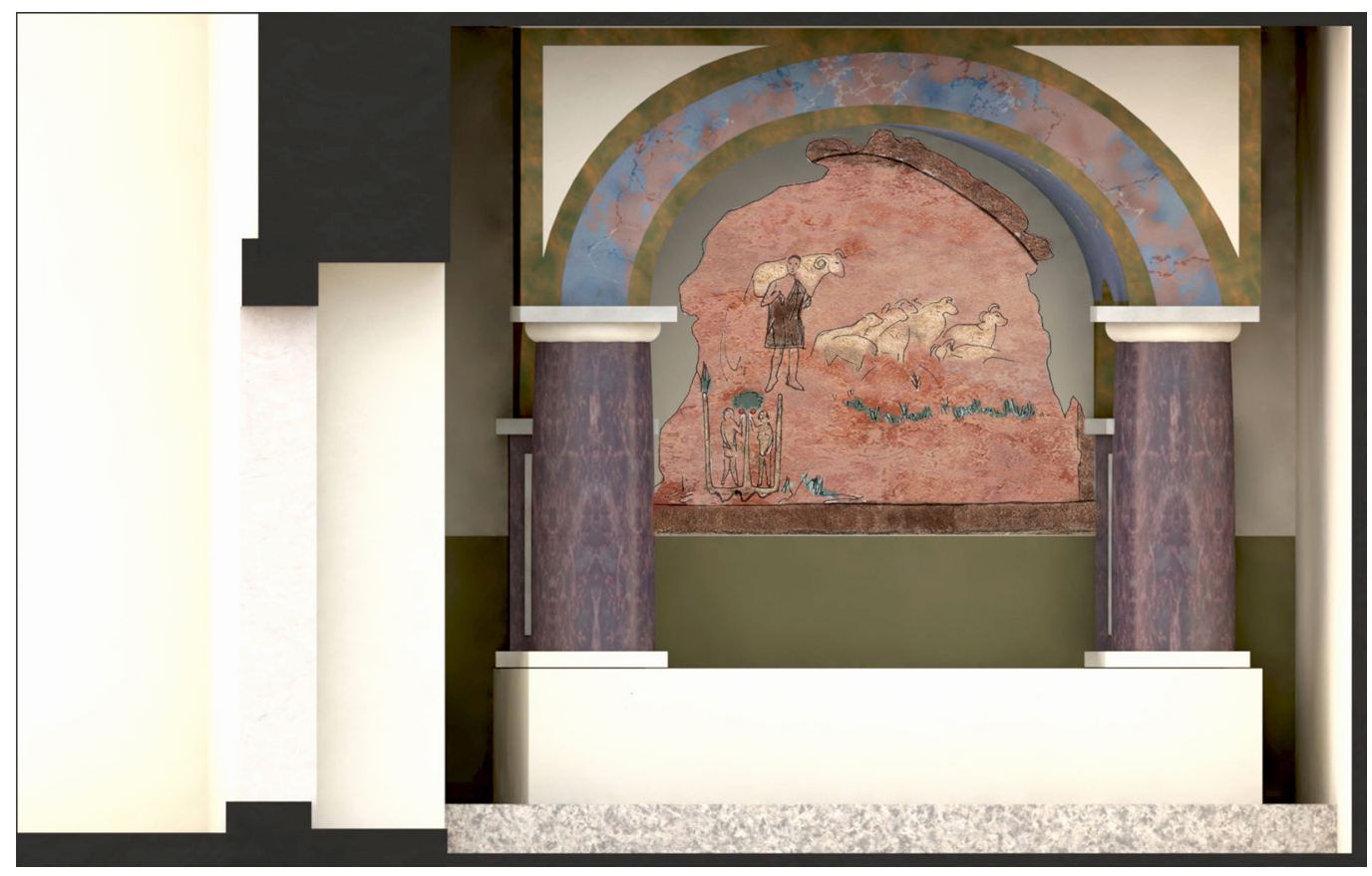


vicini [Bisconti 20 I4, p. 508]. C'è un linguaggio comune tra Oriente ed Occidente. Troviamo gli stessi temi iconografici in tutto il resto dell'Orbe, temi che si stavano sviluppando e diffondendo nello stesso periodo. La scena di Davide e Golia è presente anche nel vestibolo superiore delle catacombe di San Gennaro a Napoli. La stessa catacomba ospita una tra le più antiche rappresentazioni di Adamo ed Eva, raffigurati anche nel cimitero di Cimitile a Nola. Negli stessi anni la scena della samaritana al pozzo e quella della guarigione del paralitico compaiono in uno dei monumenti funerari più antichi, il cubicolo A3 dei Sacramenti presso l'area I callistiana, la cui esecuzione si può collocare nello stesso periodo delle pitture di Dura Europos quindi tra gli anni 230-240, e che si lega probabilmente all'entourage ecclesiastica [Bisconti 2014, p. 508]. L'artifex ripropone nella catacomba romana gli stessi temi iconografici, ma con una variazione nello schema, secondo un processo di riduzione ed un linguaggio abbreviato e sintetico [Ferri 20।5, p. 95]. La guarigione del paralitico e la samaritana al pozzo compaiono rispettivamente anche, nella cosiddetta Cappella Greca del Cimitero di Priscilla e nel cosiddetto cubicolo della Coronatio della catacomba di Pretestato. In Occidente abbiamo dunque un linguaggio più sintetico ed abbreviato rispetto a quello dell'ambiente-battistero di Dura Europos.

I primi decenni del III secolo, sono quindi gli anni in cui gli artisti stavano formulando un vero e proprio linguaggio figurativo attraverso sperimentazioni e "prove di laboratorio" [Ferri 20 I, p. 9I; Bisconti 2006, p 66]. Sono degli artifices alle prime armi, in un momento in cui "traducevano" con i colori le pagine scritte della Bibbia. Siamo dunque all'inizio di quel processo di formazione e sviluppo del linguaggio figurativo delle comunità cristiane, momento nel quale circolavano a livello globale stessi temi iconografici, la cui derivazione si potrebbe rintracciare nelle Bibbie miniate [Bisconti 1996, p. 76].

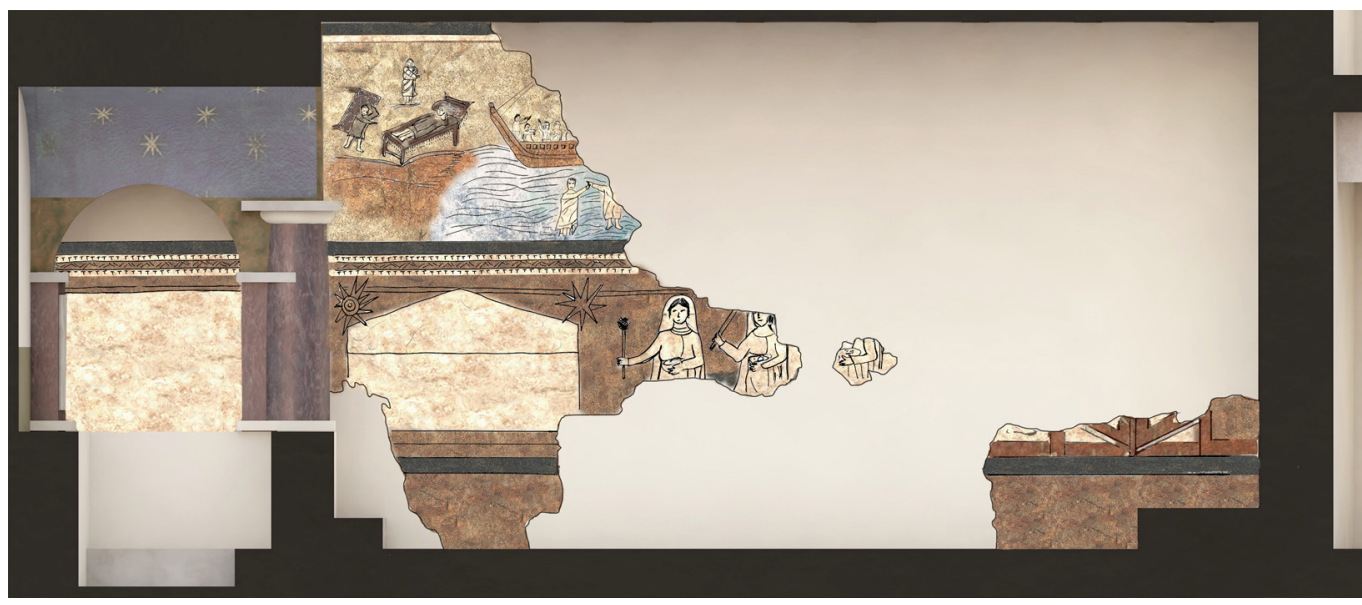

Fig. 6. Davide e Golia; la samaritana al pozzo. Inserimento dello schizzo di studio nel modello

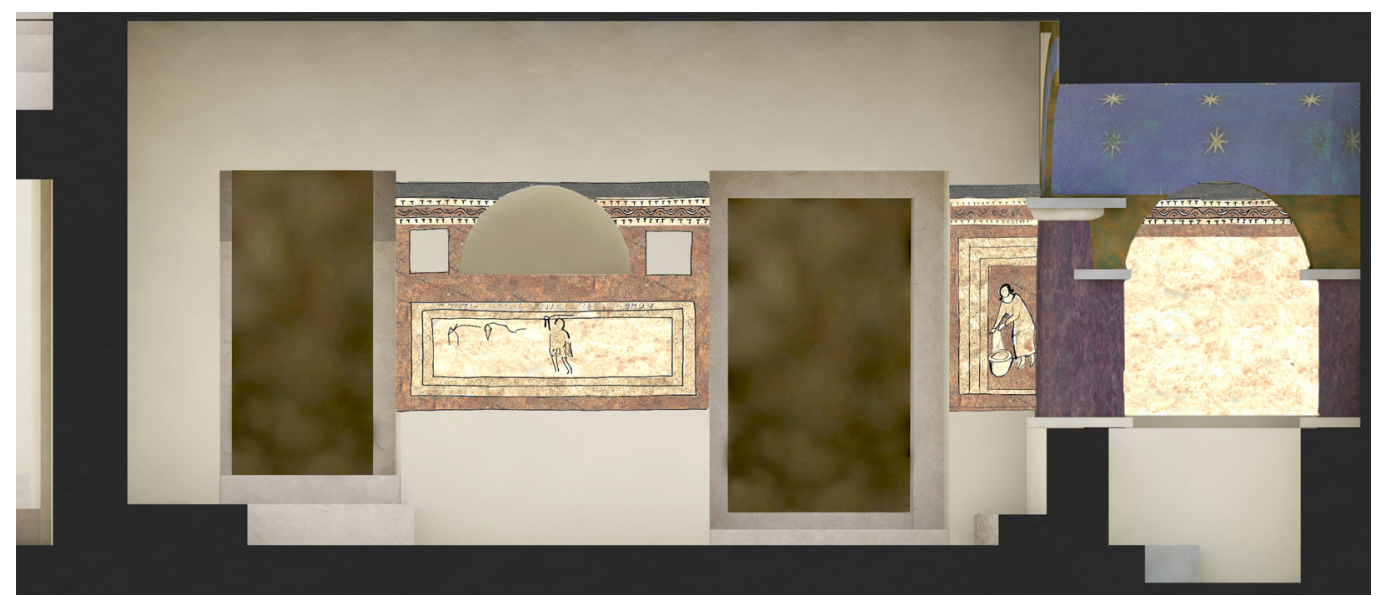




\section{Linguaggio morfologico architettonico}

La chiesa, riferibile alla fase 2A dello sviluppo degli edifici per il culto cristiano, così come tale sviluppo è stato interpretato da Olof Brandt [Brandt 2016, p. I5], segna il passaggio da una fase in cui l'architettura cristiana ci è nota soltanto attraverso le fonti letterarie, fase I, ad un momento in cui vediamo finalmente emergere segni di trasformazione che determinano la definizione di spazi permanentemente adibiti al culto cristiano. Gli ambienti cultuali, il battistero, la sala per la celebrazione eucaristica, sono ricavati attraverso modeste trasformazioni di un'abitazione già di per sé modesta. Con una pianta quadrangolare, i cui lati non raggiungono i venti metri di lunghezza, l'edificio, realizzato in mattoni crudi, si sviluppa, ad eccezione di un piccolo ambiente sovrastante il battistero, su di un unico livello. Lo stile è semplice, in linea con il carattere dell'edilizia residenziale della città, e la corte centrale, intorno alla quale si organizzano gli ambienti, è introdotta da un accesso discreto che poco lascia intravedere dall'esterno, così come discrete e quasi anonime appaiono le pareti esterne dell'edificio.

Il lungo processo di rovina che ha investito la città e l'edificio, è stato certamente accelerato, oltre che dalle operazioni di scavo e di traslazione a cui già si è accennato, dall'ultimo conflitto armato che ha investito l'area. "Nel 2014 con la regione sotto il controllo di Daesh (Stato Islamico), circa 400 gruppi di persone stavano lavorando nel sito in particolare alla ricerca di monete, alcune con macchinari pesanti, altre con metal detector"' [Baird 2020, p. I2]. L'azione erosiva degli agenti atmosferici, l'operato indisturbato dei tombaroli [8], l'instabilità politica che si è protratta nell'area, ed in ultimo l'accendersi dell'emergenza sanitaria, hanno ricondotto lo studio di questa architettura, ad un'operazione di analisi da svolgersi sul materiale edito, senza poter prendere in considerazione l'idea di effettuare un proprio viaggio di ricognizione. Sono state acquisite le tavole di rilievo realizzate da Henry Pearson e pubblicate per la prima volta in Final Report VIII, part II [9] unitamente al repertorio fotografico incluso nello stesso, ed alle sezioni inerenti alla proposta di ricostruzione dell'edificio nella sua fase cristiana (fig. 7). Pearson, è molto accurato nel fornire dettagli costruttivi, indicazione dei materiali ed annotazioni relative alle trasformazioni.

In una prima fase sono state studiate e digitalizzate le piante dell'edificio relative ai due momenti (fig. 8), prima e dopo della trasformazione in luogo di culto [I 0], le sezioni [I I] ed i dettagli costruttivi [ I2]. Tale analisi ha permesso di dar luogo alla modellazione tridimensionale dell'edificio ed alla conseguente realizzazione di elaborati renderizzati (fig. 9). L'ipotesi ricostruttiva si basa pertanto sugli schemi forniti dal Pearson e sull'idea di uniformità urbana, da riferirsi alle caratteristiche morfologiche del tessuto edilizio della città. Si è proceduto

Fig. 7. Sezioni dell'edificio. Ricostruzione di Henry Pearson in Final Report

Fig. 8. Piante delle due fasi dell'edificio; pianta M8 ed inserimento assonometrico (elaborazione grafica Francesco Stilo).
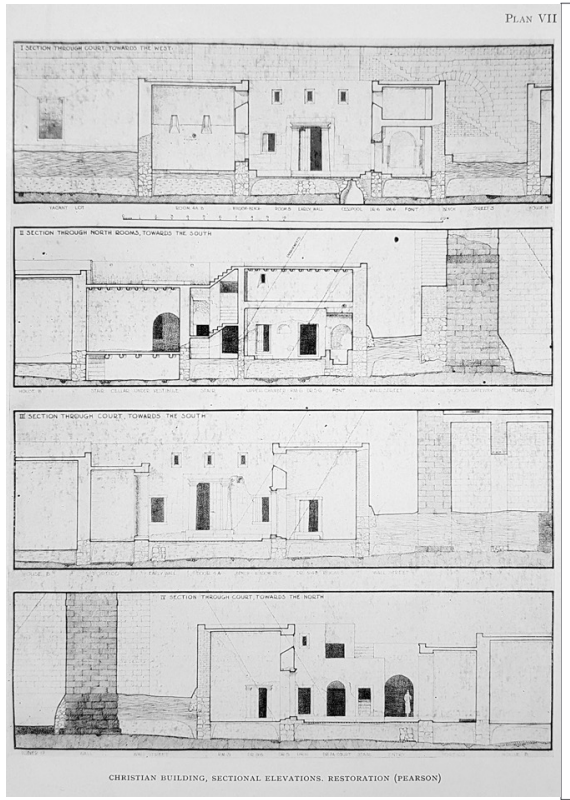

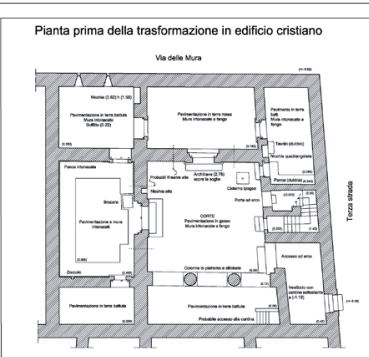

$\theta$

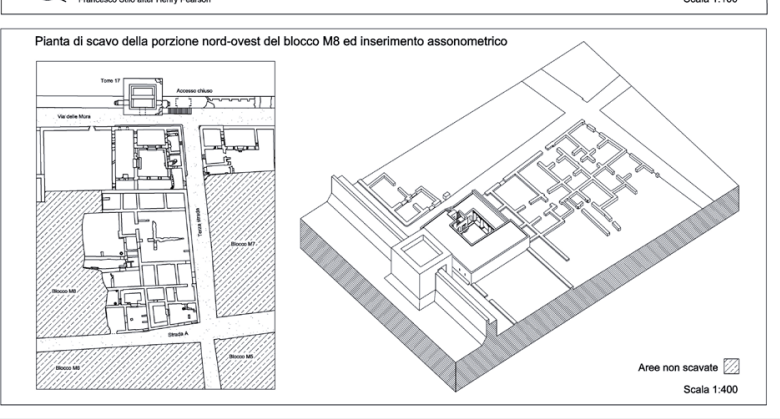


Fig. 9. Viste assonometriche dell'edificio. Modello

renderizzato (elaborazion

Fig. 10. Analisi morfologica dell'edificio. Modello

renderizzato (elaborazione grafica Antonio Femia).
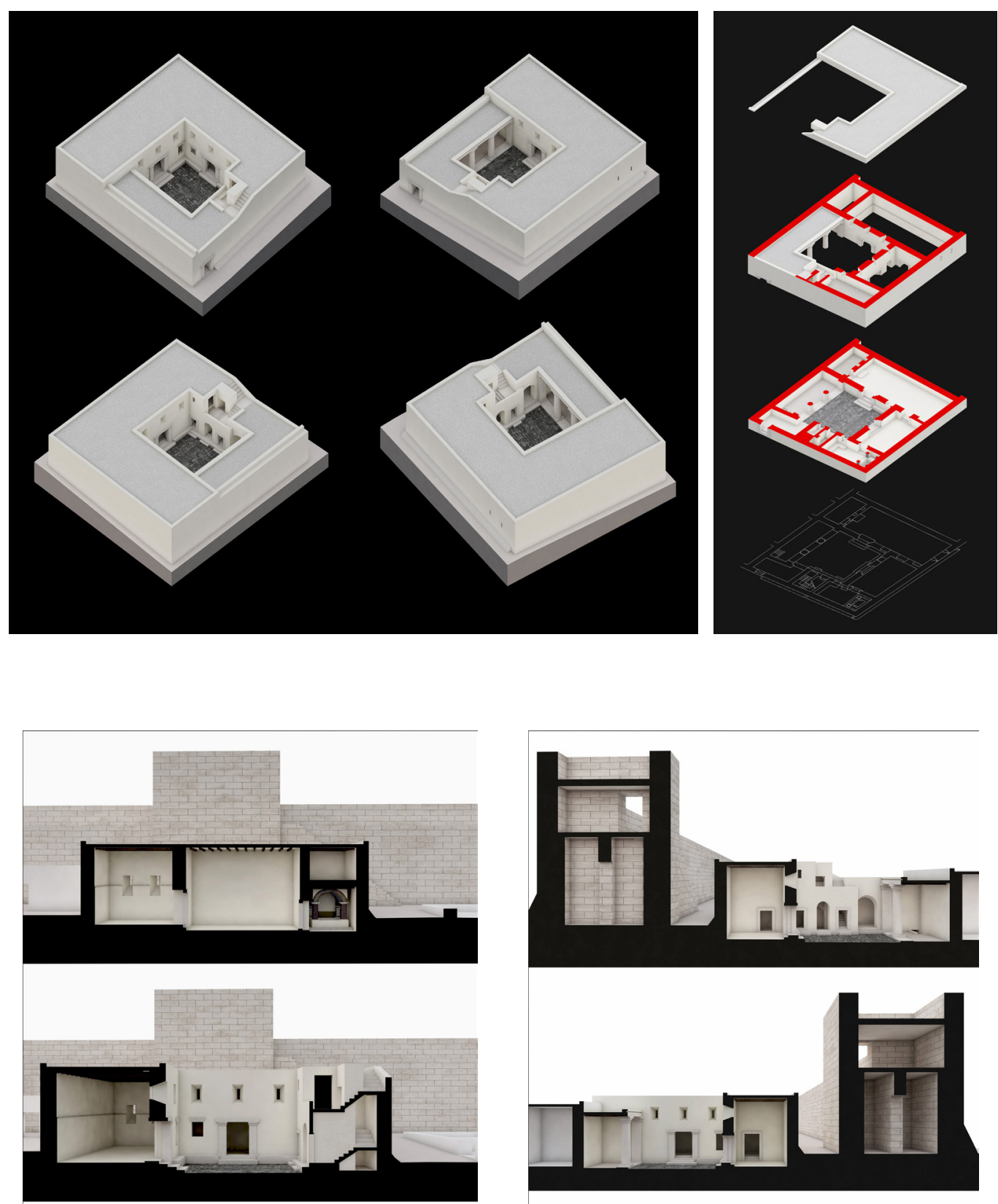

Fig. II. Sezioni prospettiche renderizzate (elaborazione grafica Antonio Femia)

Fig. 12. Sezioni

prospettiche renderizzate ((elaborazione grafic
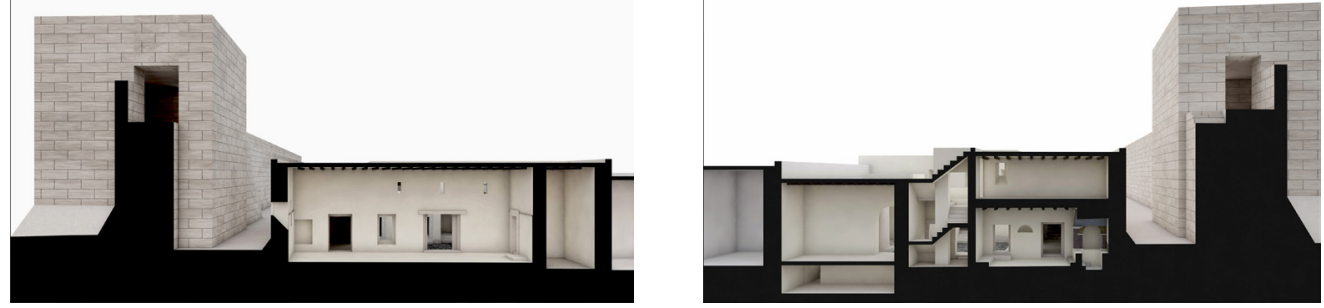
quindi alla digitalizzazione della tavola relativa alla pianta del blocco M8 [13] in cui l'edificio risulta essere inserito, ed al ridisegno della pianta schematica della città. Una rapida analisi morfologica identifica in schemi assonometrici l'orografia del sito, il sistema di fortificazioni costituito dalle mura della città e della cittadella e dalle relative torri, e il tessuto urbano di tipo ippodameo.

Si intendono così fornire delle immagini iconiche che possano trasmettere la forma dell'edificio al tempo della sua piena attività (fig. I0- I2), unitamente alle elaborazioni in scala I: I000 relative alla forma urbana. II presente lavoro vuole fare inoltre riferimento al contesto di ricerca inerente allo studio morfologico delle città delle sabbie, realtà fragili rispetto alle quali, come scrive Gaetano Ginex: "continuando l'erosione delle deboli tracce ormai quasi dissolte nella sabbia, è probabile che possano scomparire per sempre lasciando solo la memoria di esse" [Ginex 20 17, p. 17]. Lo sviluppo di un ambiente essenzialmente archeologico in ambiente architettonico, si potrebbe configurare nel proseguo di questo studio, in una più approfondita ricostruzione tridimensionale della città qui presentata e/o nell'analisi degli altri edifici di culto tra i quali la sinagoga ed il mitreo.

\section{Note}

[I] Dal sito proviene una discreta quantità di documentazione scritta. I papiri e le pergamene più frequenti sono in latino (riferibili alla guarnigione di stanza nella città), in greco (di tipo contrattuale e come frammenti di opere letterarie). Più scarsa è la letteratura in lingue semitiche: "una pergamena liturgica della sinagoga, in ebraico, un contratto di vendita di una schiava in protosiriaco e una pergamena, forse un testamento, in aramaico giudaico babilonese. Sono inoltre state trovate tre pergamene in persiano" [Grassi 2007, p. 268]. Ingente è inoltre la documentazione epigrafica:"I testi delle epigrafi, pur con la netta prevalenza del greco, testimoniano l'uso, oltre che del latino, limitato ai soldati e alle dediche imperiali, di vari dialetti aramaici (palmireno, hatreo, giudeo-aramaico, protosiriaco), del safaitico, del partico e del medio persiano" [Grassi 2007, p. 269].

[2] "Emenso itaque itinere bidui prope civitatem venimus Duram desertam marginibus amnis impositam. In quo loco greges cervorum plures inventi sunt, quorum alii confixi missilibus, alii ponderibus illisi remorum ad satietatem omnes paverunt; pars maxima natatu assueta veloci alveo penetrato incohibili cursu evasit ad solitudines notas" (Ammiano, Rerum Gestarum, 24.1.5).

[3] Scavi più recenti sono stati condotti, a partire dal 1986, all'interno di un accordo franco-siriano e guidati da P. Leriche.

[4] Sugli edifici precostantiniani e le fonti, rimando a Guidobaldi 20 I4, pp. 36I-443.

[5] Formalmente l'edificio si è presentato agli occhi degli scopritori, come una comune abitazione di Dura: "In character the structure is simply a typical private house of Dura, modified slightly to adapt it to religious use. The entrance is unobtrusive, an ordinary doorway leading in from street 3 at the northeast corner of the building"' [Bradford Welles 1967, p. 3].

[6] Per quanto riguarda l'architettura dei primi cristiani si veda: Brandt 2016.

[7] Sulla guarigione del paralitico vedi Ferri 2015.

[8] Indagini aeree e satellitari mostrano come la città appaia oggi come una grande groviera costellata di grosse buche.

[9] Testo a cui si rimanda per una puntuale descrizione dell'edificio e delle sue fasi.

[I0] Plan IV e Plan V.

[ I I] Plan VII.

[12] Plan VI e Plan VIII.

[ 13] Plan II.

\section{Riferimenti bibliografici}

Baird J.A. (2020). The Ruination of Dura-Europos. In Theoretical Roman Archaeology Journal. 3 ( I), p. 2. <https://traj.openlibhums. org/articles/10.16995/traj.421/> (consultato il 25 gennaio 2021).

Bisconti F. (1989). Le rappresentazioni urbane nella pittura cimiteriale romana: dalla città reale a quella ideale. In Actes du Xle Congrès International d'Archéologie Chrétienne, Roma, Città del Vaticano: Pontificio Istituto di Archeologia Cristiana, pp. 1305 1321 .

Bisconti F. ( 1996). Genesi e primi sviluppi dell'arte cristiana: i luoghi, i modi, i temi. In A. Donati (a cura di). Dalla terra alle genti: la diffusione del Cristianesimo nei primi secoli (Catalogo della mostra, Rimini, 31 marzo- ${ }^{\circ}$ settembre 1996), Milano, pp. 7 I-93. Bisconti F. (20|4). Immagini cristiane della tarda antichità. In Lezioni di Archeologia Cristiana, pp. 50 I-583.

Bisconti F. (2000a). Programmi figurativi. In E. La Rocca, E. Ensoli (a cura di). Aurea Roma dalla città pagana alla città cristiana. Roma: L'Erma di Bretschneider. 
Bisconti F. (2000b). Temi di iconografia paleocristiana. Città del Vaticano: Pontificio Istituto di Archeologia Cristiana.

Bisconti F. (20 I0). Il tesoro nascosto della Pompei d'Oriente. L'affresco della Domus Ecclesiae di Dura Europos è il più antico sul tema delle donne al sepolcro vuoto. In Osservatore Romano n. 78, 4 aprile 20 I 0, p. 4.

Bisconti F. (20 I I). Le pitture delle catacombe romane: restauri e interpretazioni. Pian di Porto:Todi Tau.

Bisconti F., Braconi M. (2012). II riuso delle immagini in età tardoantica: L'esempio del Buon Pastore dall'Abito Singolare. In Antichità Altoadriatiche 74, pp. 231 -240.

Bradford Welles C. (a cura di). (1967). The excavations at Dura-Europos conducted by Yale University and The French Academy of Inscriptions and Letters, Final Report VIII, part II. New Haven: Dura-Europos publications.

Brandt O. (2016). La croce e il capitello: le chiese paleocristiane e la monumentalità. Città del Vaticano: Pontificio Istituto di Archeologia Cristiana.

Bucolo R. (2009). La samaritana al pozzo nel cubicolo A3 della catacomba di S. Callisto tra funzione iconografica e interpretazione patristica. In Rivista di Archeologia Cristiana 85, pp. I07- 124.

Ferri G. (2015). Ecce sanus factus es, iam noli peccare. Spunti e riflessioni sull'iconografia del miracolo della guarigione del paralitico nella pittura cimiteriale cristiana delle origini. In Vetera Christianorum 52, pp. 87- 109.

Ginex G. (20/3). Città del mito: la cittadella di Aleppo. “Un progetto di rappresentazione per preservarne l'identità". In A Conte, M. Filippa (a cura di). Patrimoni e siti UNESCO. Memoria, misura e armonia. Atti del $35^{\circ}$ convegno dei docenti della rappresentazione, X Congresso UID, Matera, 24/26 ottobre 2013, pp. 483-493. Roma: Gangemi editore.

Ginex G. (2017). Nefta e le città oasi di Tamerza, Mides e Chebika. Reggio Calabria: Iriti.

Grassi F. G. (2007). L'onomastica di Dura-Europos. In Kaskal. Rivista di storia, ambienti e culture del Vicino Oriente Antico, vol. 4 pp. 267-295.

Guidobaldi F. (20|4). Architettura paleocristiana. In F. Bisconti, O. Brandt (a cura di). Lezioni di Archeologia Cristiana (Sussidi allo studio dell'Archeologia Cristiana, 27), Città del Vaticano, pp. 36I-443.

Hopkins C. (1934). The Cristian chapel at Dura-Europos. In Pontificio Istituto di Archeologia Cristiana (a cura di). Studi di antichità cristiana. Atti del III Congresso internazionale di Archeologia Cristiana. Ravenna, 25-30 settembre 1932, pp. 483-492. Roma: PIAC.

Peppard M. (2016). The World's Oldest Church. Bible, Art, and Ritual at Dura-Europos, Syria. New Haven and London: Yale University Press.

Pergola A. (20 I0). La discussa scena delle donne al sepolcro nel battistero di Dura Europos. Alle origini dell'iconografia della resurrezione di Cristo. In Rivista di Archeologia Cristiana 86, pp. 315-352.

Rostovtzeff M. ( 197 I). Città Carovaniere. Bari: Editori Laterza. [Prima ed. Caravan Cities. London: Clarendon Press, I932].

Stilo F. (2020). L'enigma del Monastero di Santa Barbara. Tra storia e rappresentazione. In A. Arena et al. (a cura di). Connettere. Un disegno per annodare e tessere. $42^{\circ}$ Convegno internazionale dei docenti delle discipline della rappresentazione, pp. $2736-2757$. Milano: Franco Angeli.

Wolfgang S. (a cura di). (1978). Ammiani Marcellini Rerum gestarum libri supersunt. Leipzig: B.G. Teubner.

\section{Autori}

Francesco Stilo, Università degli Studi Mediterranea di Reggio Calabria, francesco.stilo@unirc.it

Crystel Mamazza, Pontificio Istituto di Archeologia Cristiana, crystelmamazza3@gmail.com.

Per citare questo capitolo: Stilo Francesco, Mamazza Crystel (2021). Architettura sacra lungo le sponde del fiume Eufrate. Dura-Europos, il primo edificio di culto cristiano/Sacred architecture along the banks of the Euphrates River. Dura Europos, the first building for Christian worship. In Arena A. Arena M. Mediati D. Raffa P. (a cura di). Connettere. Un disegno per annodare e tessere Linguaggi Distanze Tecnologie. Atti del $42^{\circ} \mathrm{Conveg}$ no Internazionale dei Docenti delle Discipline della Rappresentazione/Connecting. Drawing for weaving relationship. Languages Distances Technologies. Proceedings of the $42^{\text {th }}$ International Conference of Representation Disciplines Teachers. Milano: FrancoAngeli, pp. I | 6 | I I I 78. 


\title{
Sacred Architecture Along the Banks of the Euphrates River. Dura Europos, the First Building for Christian Worship
}

\author{
Francesco Stilo \\ Crystel Mamazza
}

Abstract

The present essay refers to one of the most emblematic case studies in relation to the investigations of the materials elements of early Christian worship, seen from a triple perspective: archaeological, architectural, iconographic. To this day the church of Dura Europos is the most ancient building, among whose walls, starting from the first half of the III century, for sure, Christian worship was celebrated. A short introduction about the historical origin of the city, clear the way for the development of two languages: the pictorial/iconographic one, concerning a review of the frescoes contained in the building's baptistry, and the morphological/architectural one, developed in procedures of analysis, redesign and three-dimensional modeling of the architectural elements. The study proposes a synthetic view of the dealt case, thus focusing on the production of iconic images that can give the idea of the building's shape at the peak of its use. The proposed reconstructions are based on the acquisition and digitization of the survey drawings produced by Henry Pearson and published in Final report VIII, part II. It is important to preserve the memory of a site already compromised and exposed to a continuous risk, and to contribute to its knowing through the language of drawing. This fact means re-establishing, in a moment of great uncertainty and crisis, relations with a fragile past and in constant risk of oblivion, projecting the history of our civilization into the future.

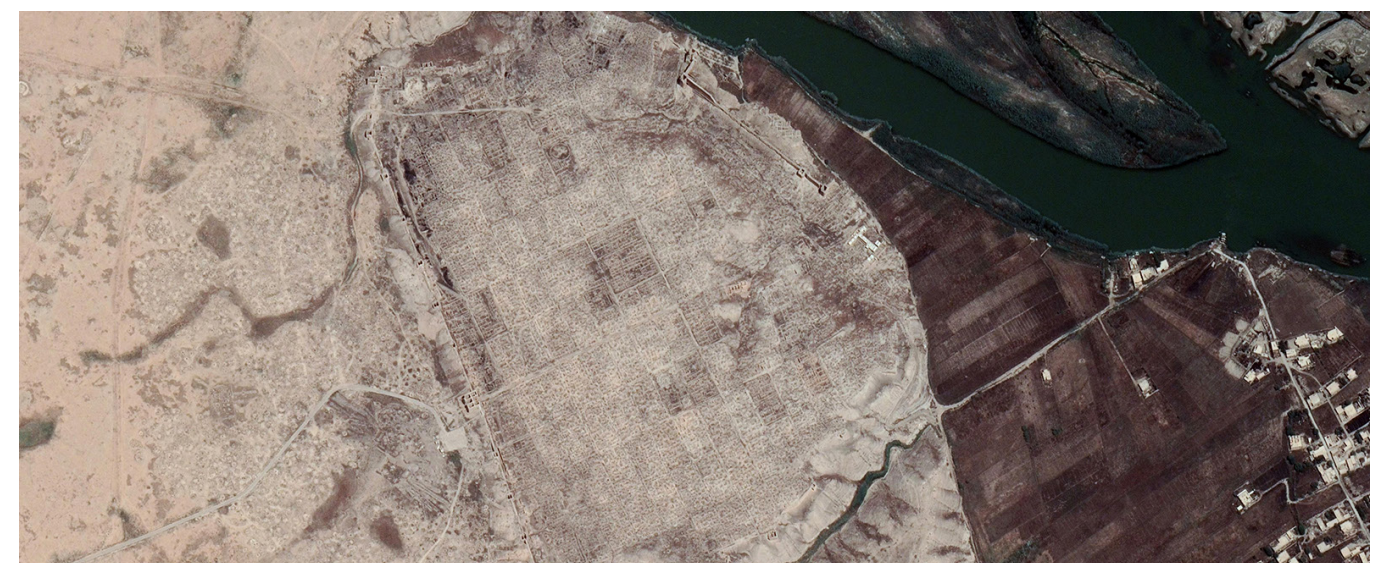




\section{Introduction}

Rereading the verses with which Michael Rostovtzeff describes his journey to reach the ruins of Dura, one feels a strange nostalgia for a time when archaeological research in the sands of the Near East was adventure and risk. In 1928, although the camel was replaced by the car tire, at least for the western traveler, the route to Dura was still uncertain and dangerous. The desert served as an immense and treacherous road, and groups of Bedouins with an anarchic temperament, it is said, threatened the journey, looking for young European girls to be inserted in some sheikh's harem. Among the caravan routes (fig. I) frequented at the time of the Seleucids, those that led from Antioch on the Orontes to Seleucia on the Tigris were, according to the Russian historian, the most interesting. Rostovtzeff, frequenting these routes, at the time of writing, describes a landscape in which life appeared "hardly changed since the days of the great Antiochs, or even from Babylonian, Hittite or Assyrian times" [Rostovtzeff 1971, p. 16 I]. The landscape was dotted with traditional Roman and Byzantine architecture, while a powerful natural backdrop enveloped the space.

Dura was founded in the IV century BC by the Hellenistic dynasty of Seleucids and in the II century came under the control of Parthians. Situated on a rocky plain eroded to the north east by the Euphrates river, so much so that a portion of the city, and in particular the citadel, of which very little remains, over the centuries has been slowly swallowed up. The city, that has an Hippodamian plan (fig. 2, 3), it took shape already in the first century BC. as a frontier fortress, a multicultural place, a jumble of languages [ $\mathrm{I}$ ] and religions. Definitely conquered by the Romans during the Parthian campaigns carried out by Lucio Vero 161-166 $A D$, the city was incorporated into the province of Syria, remaining under the control of the empire until the Sassanid conquest in the mid-third century. Dura appeared deserted when Ammianus Marcellinus described the place as populated by herds of deer [2]. Discovered in 1920 by a British soldier under Captain Murphy, Dura was the subject of excavations between the 1920s and 1930s, conducted by French and American teams, led by F. Cumont first, and M. Pillet and C. Hopkins then [3].

Among the many religious buildings that crowd the city, particular interest has aroused the discovery of the pre-basilica church, a building of considerable importance, not only because it confirms the presence of a pre-Constantinian place of worship [4], although not built ex

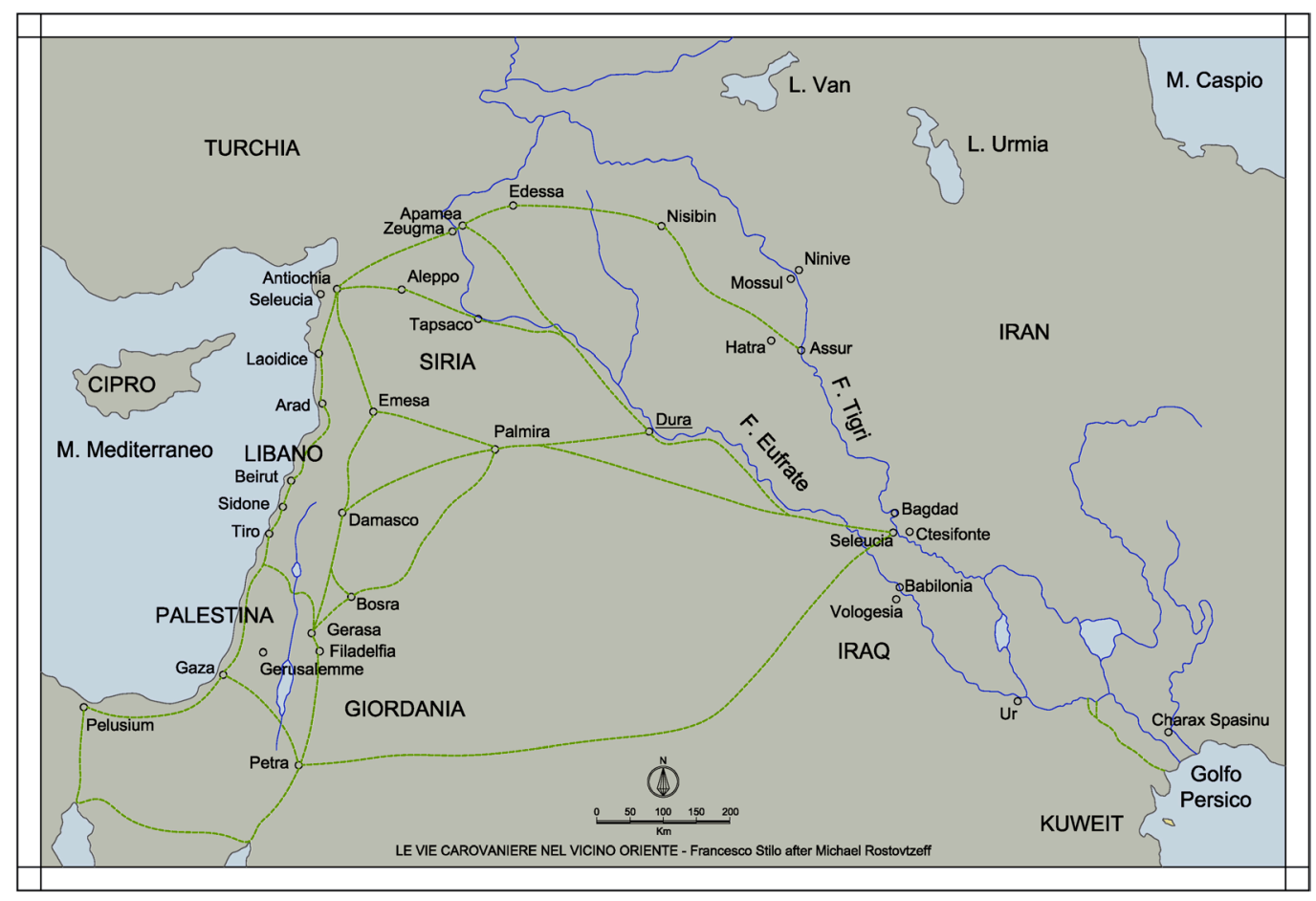




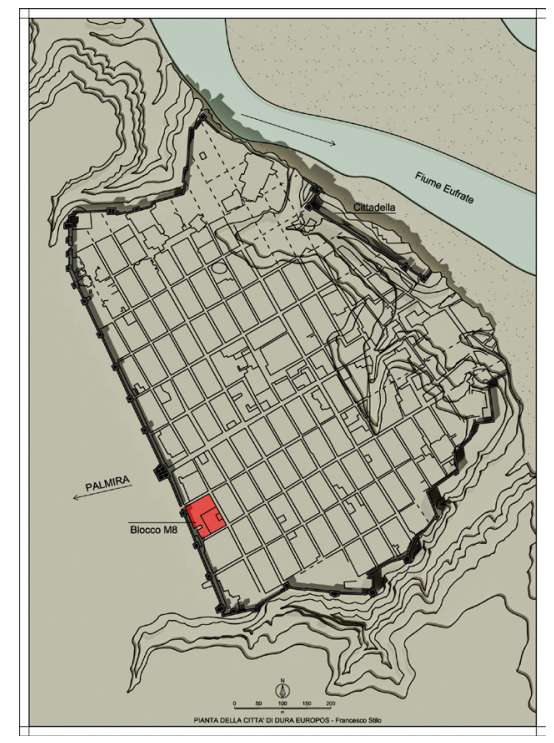

novo, but also because it left us one of the most important and ancient Christian figurative documents. From the architectural point of view, the building [5] does not show the elaboration of a Christian language [6], but as regards the pictorial apparatus, it marks the beginning of a truly Christian art [Bisconti 20 I I, p. 35]. The privileged object of the discussion is the baptistery-environment decorated with paintings from the Old and New Testament, which, after several restorations, are now preserved at the Yale Gallery of Fine Arts at New Haven, in a museum and therefore decontextualized from their place of origin.

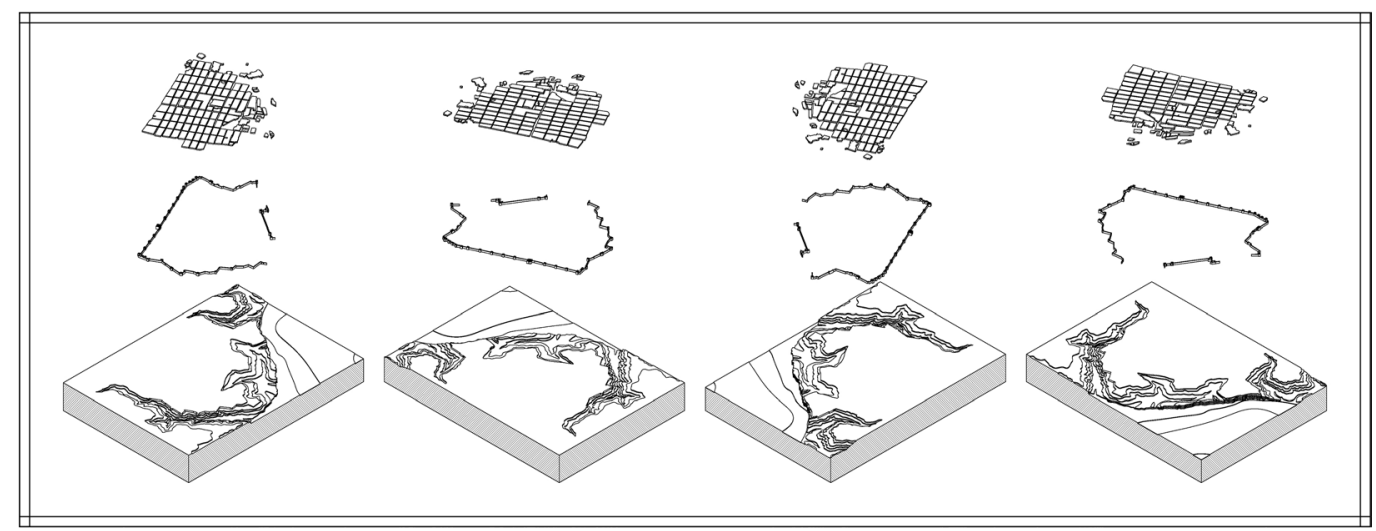

Iconographic pictorial language

The environment-baptistry is characterized by the baptismal font on the back wall, introduced by two columns in faux marble, and by two lateral walls on which there are biblical scenes. On the vault of the lunette of the back wall, there is the representation of the starry sky, a symbol of illumination. On the same lunette there is also the representation of the Good Shepherd with the flock (fig. 4). The figure of the shepherd in the Late Antique period assumes new meaning that must be read in a Christian key. In the moment of transformation of meanings during Christian period, the shepherd becomes a symbol of salvation [Bisconti, Braconi, 20 I 2, p. 229], thus it is interpreted as image of Christ who following the parable of the lost sheep (Vangelo, Luca (15,3-7), Matteo (18,|12-14)] saves the lost soul [Bisconti 2000a, p. $31 \mathrm{I}$ ]. Thus, there is a continuum between pagan and Christian figurative 
culture. In the baptistery of Dura Europos there is the depiction of the Good Shepherd as a symbol of salvation. In the lower part of the lunette, precisely on the left, there is a barely legible image, of Adam and Eve. The proto-parents stand on a ground line, flanking a tree with a coiled snake. Basically, early Christian art is an auspicious and positive art, there are rare and sporadic cases in which scenes of passion or sin are depicted, or in general scenes of violence [Bisconti 2000b, p. 4 I]. In the case of Dura Europos, the scene of the proto-parents is necessary; they are those who represent the felix culpa essential for the fulfillment of the divine plan of salvation [Bisconti 201 I, p. 22].

Regarding the decoration of the lateral walls, we can see on the upper register of the North wall (fig. 5), the scene of the healing of the paralytic [7], that is very popular in early Christian art. In the same wall, there is a rare episode, Peter on the waves saved by Christ, who represents a symbol of salvation. The water is an element that repeats often in the paintings of the baptistery of Dura Europos, being the meaning of regeneration [Bisconti 20 I2, p. I3], certainly referring to a baptismal meaning. In the lower register of the North and East walls there is the depiction of a scene with large figures illustrating the episode of the pious women at the tomb. The scene, which was considered the oldest representation of the Resurrection of Christ [Bisconti 20 I 0, p. 4], is well suited to the baptistery environment due to the profound link that is triggered between resurrection and illumination, indicating the importance for Christians of the victory of Christ on death [Bisconti 20 I0; Pergola 20 I0, p. 323]. The concept of victory and triumph also appears in another episode located on the south wall (fig. 6), which features the characters of David and Goliath, alluding to the theme of the struggle of good against evil. Another scene that decorates the environment is that of the Samaritan woman at the well. The woman, represented as an isolated character, is depicted in the foreground as she bends down to collect water from the well. It can be seen how the various New Testament scenes are linked together by a red thread and, as Fabrizio Bisconti writes, by a strongly baptismal leitmotif [Bisconti 2000b, p. 28].

In conclusion, it can be said that this decorative program is reflected in the rest of the orbis christianus antiquus, in particular in the Roman catacomb painting, thus putting "distant poles in contact by geography and by monumental typology" [Bisconti 20।4, p. 5I2].

Common characteristics can be found, not only as regards the themes, but in some cases also for the schemes, demonstrating that there is a "common iconographic denominator" [Bisconti 201 I p. 20]. "The process of Christianization therefore touches distant but close places" [Bisconti 20 I4, p. 508]. There is a common language between East and West. We find

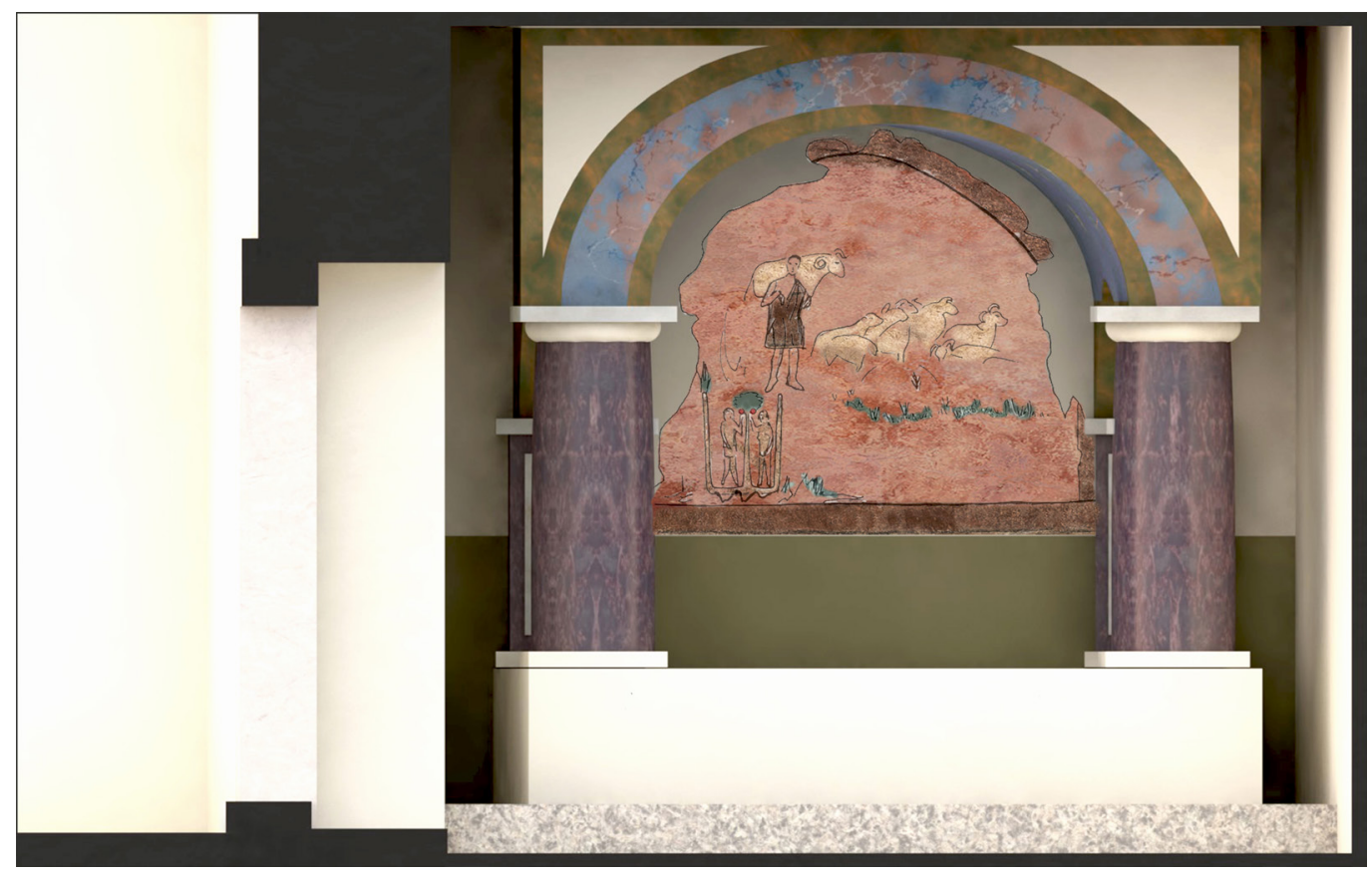


the same iconographic themes throughout the rest of the Orbe, themes that were developing and spreading in the same period. The scene of David and Goliath is also present in the upper vestibule of the catacombs of San Gennaro in Naples. The same catacomb houses one of the oldest representations of Adam and Eve, also depicted in the cemetery of Cimitile at Nola. In the same years the scene of the Samaritan woman at the well and that of the healing of the paralytic appear in one of the oldest funerary monuments, the cubicle A3 of the Sacraments in the so-called area prima callistiana, whose execution can be placed in the same period as the paintings of Dura Europos therefore between the years 230-240, and which is probably linked to the ecclesiastical entourage [Bisconti 20I4, p. 508]. The artifex proposes the same iconographic themes in the Roman catacomb, but with a variation in the scheme, according to a reduction process and an abbreviated and synthetic language [Ferri 20 I 5, p. 95]. The healing of the paralytic and the Samaritan woman at the well also appear respectively, in the so-called Greek Chapel of the Priscilla Cemetery and in the so-called Coronatio cubicle of the catacomb of Pretestato. In the West, therefore, we have a more concise and abbreviated language than that of the baptistery-environment of Dura Europos. The first decades of the third century are therefore the years in which the artists were formulating a real figurative language through experiments and "laboratory tests" [Ferri 20 I5, p. 9 I; Bisconti 2006, p 66]. They are novice artifices, at a time when they "translated" the written pages of the Bible with colors. We are therefore at the beginning of that process of formation and development of the figurative language of Christian communities, a moment in which the same iconographic themes circulated globally, the derivation of which could be traced in the illuminated Bibles [Bisconti 1996, p. 76].

Fig. 5. The healing of the paralytic; Peter saved pious women at the tomb. Inserting the study sketch into the $3 \mathrm{~d}$ mode (graphic elaboration by Andrea Luigi Stilo).
Fig. 6. David and Goliath; the Samaritan woman at the well. Inserting the study sketch into the $3 \mathrm{~d}$ model (graphic elaboration by Andrea Luigi Stilo)
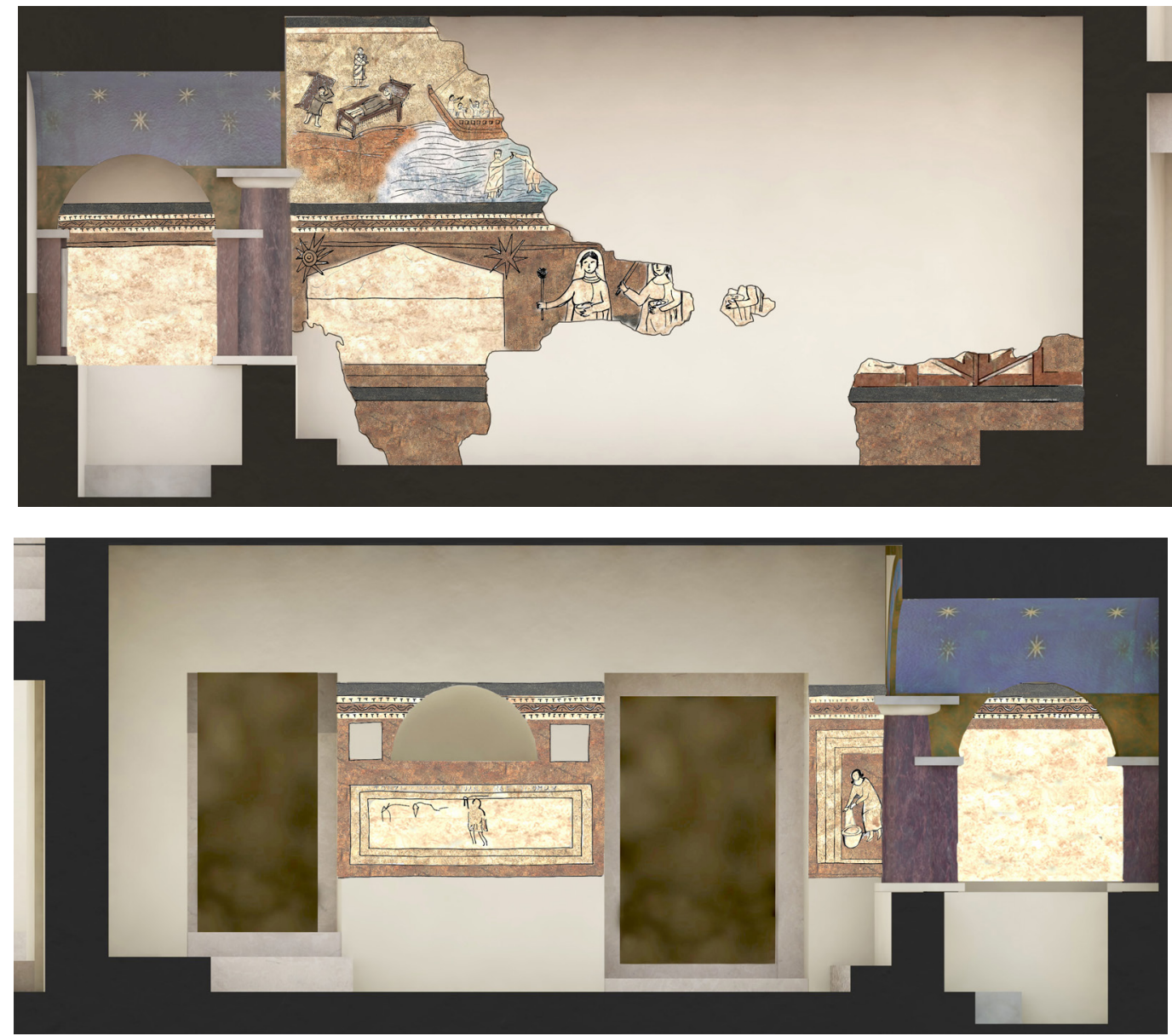


\section{Architectural morphological language}

The church, referable to phase 2A of the development of buildings for Christian worship, as this development was interpreted by Olof Brandt [Brandt 20 I 6, p. I5], marks the transition from a phase in which Christian architecture is known to us only through literary sources, phase I, at a time when we finally see signs of transformation emerge that determine the definition of spaces permanently used for Christian worship. The cult environments, the baptistery, the room for the Eucharistic celebration, are obtained through modest transformations of an already modest house. With a quadrangular plan, whose sides do not reach twenty meters in length, the building, made of unfired bricks, develops on a single level, with the exception of a small room above the baptistery. The style is simple, in line with the character of the residential buildings of the city, and the central courtyard, around which the rooms are organized, is introduced by a discreet access that allows little to be glimpsed from the outside, as well as discreet and almost anonymous the outer walls of the building appear. The long process of ruin that has damaged the city has certainly been accelerated not only by the excavation and translation operations already mentioned, but also by the last armed conflict that has affected the area. "In 2014 with the region under the control of Daesh (Islamic State), about 400 groups of people were working on the site in particular looking for coins, some with heavy machinery, others with metal detectors" [Baird 2020, p. 12]. The erosive action of atmospheric agents, the undisturbed work of grave robbers [8], the political instability that has persisted in the area, and ultimately the ignition of the health emergency, have led this study back to an operation of analysis to be carried out on the status quaestionis without then being able to consider the idea of carrying out one's own reconnaissance trip. In this sense, the survey tables created by Henry Pearson and published for the first time in Final Report VIII, part II [9], together with the photographic repertoire included in the same and the sections relating to the proposed reconstruction of the building in its Christian phase (fig. 7). Pearson, is very careful in providing construction details, indication of materials and annotations relating to the transformations.

In a first phase, were studied and digitized the plans of the building relating to the two moments (fig. 8), before and after the transformation into a place of worship [10], also the sections [ I I] and the construction details [ I 2]. This analysis allowed to give rise to the three-dimensional modeling of the building and the consequent creation of rendered elaborations (fig. 9). The reconstructive hypothesis is therefore based on the schemes provided by Pearson and on compliance with the concept of urban uniformity, to be referred to the

Fig. 7. Sections of the building. Reconstruction by Henry Pearson in Fina Report.

Fig. 8. Plans of the two phases of the building; excavation plan of the $M 8$ insertion (graphic

insertion (graphic elabora
Stilo).

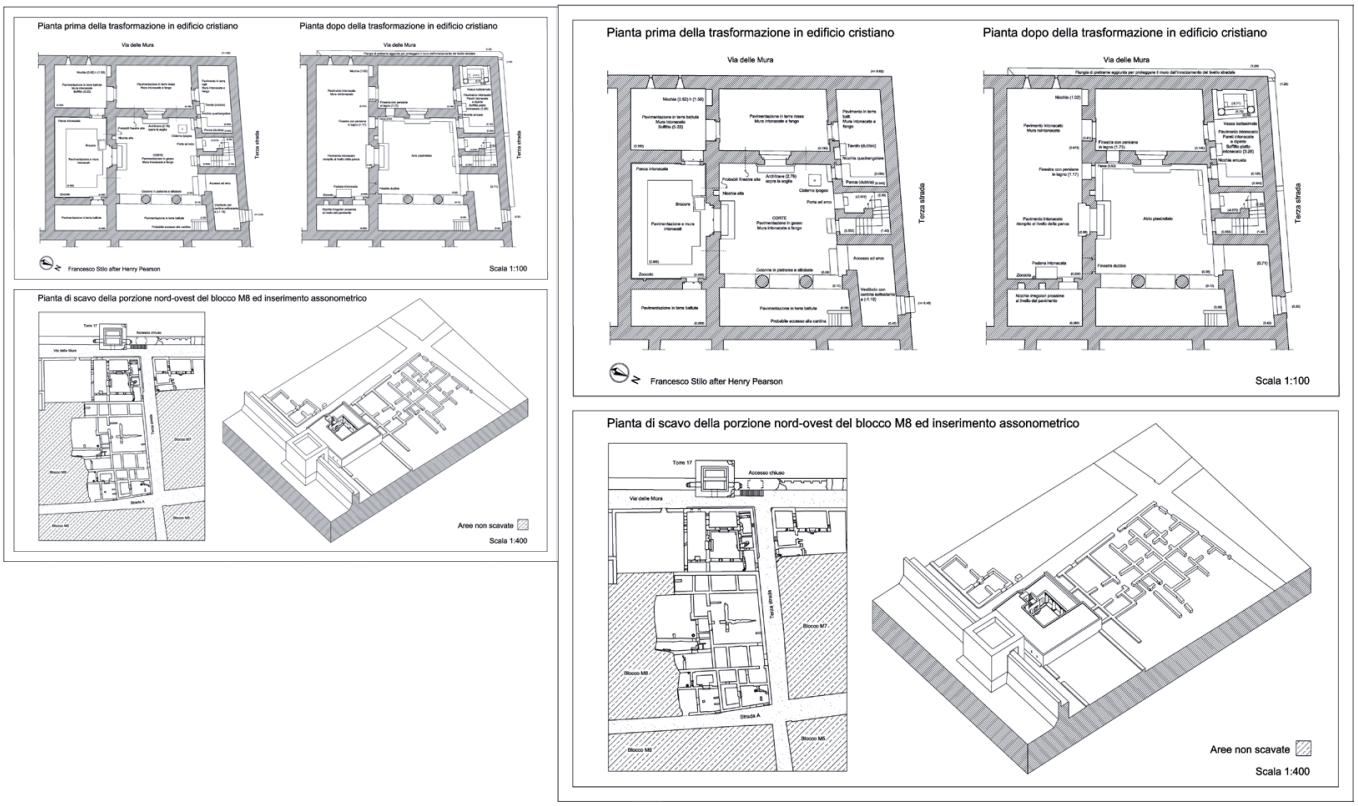


Fig. 9. Axonometric

views of the building.

Rendered model (graphic

elaboration by Antonio

emia).

Fig. 10. Morphological

analysis of the building.

Rendered model (graphic

elaboration by Antonio
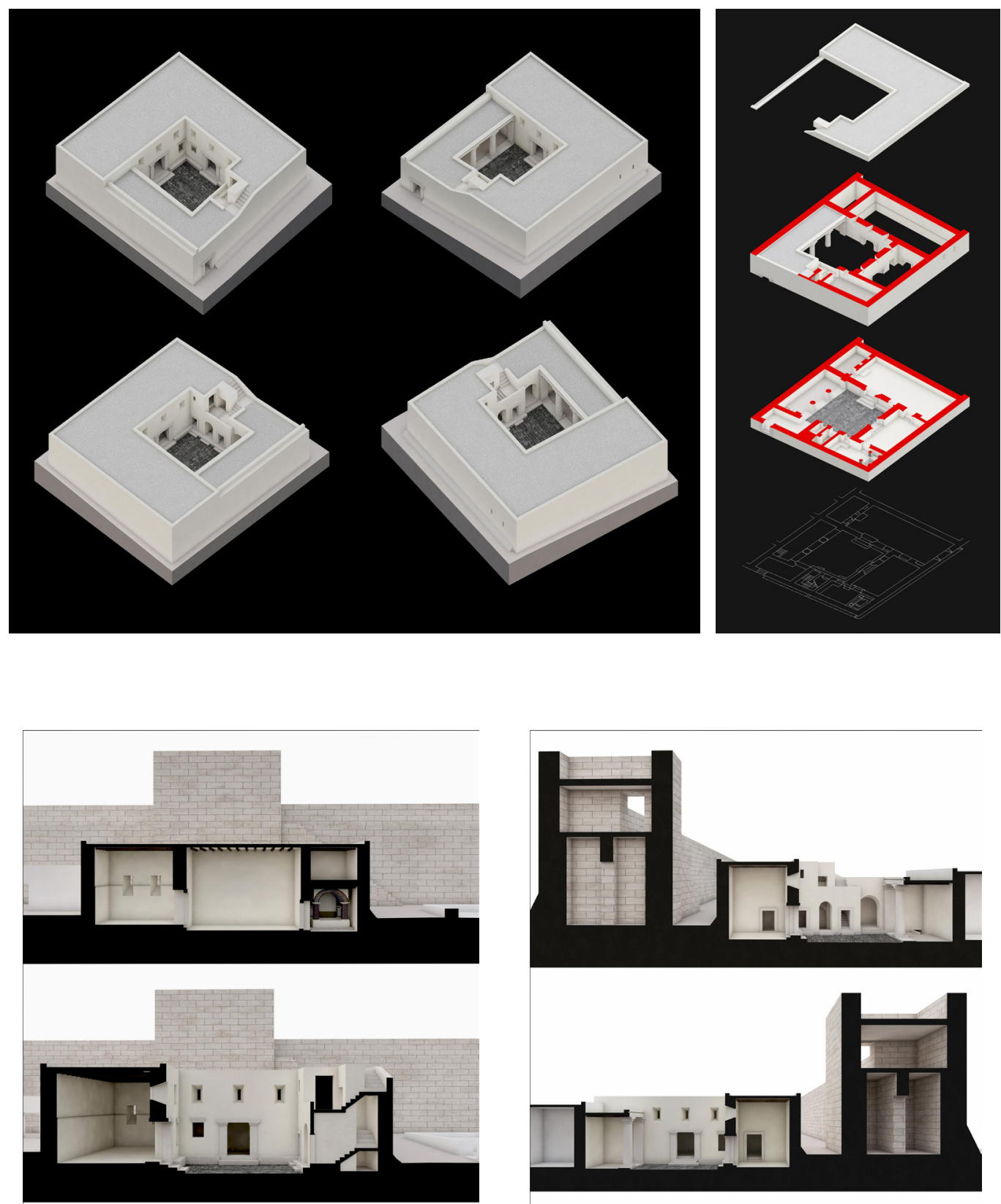

Fig. 1 1. Perspective

(graphic elaboration by

Antonio Femia).

Fig. 12. Perspective

sections rendered 2 .

(graphic elaboration by
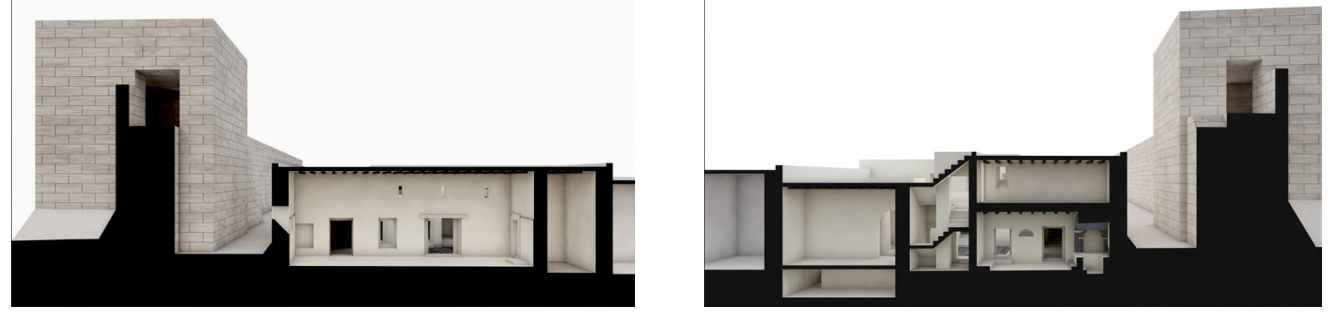
morphological characteristics of the building fabric of the city. We then proceeded to digitize the table relating to the plan of block M8 [13] in which the building appears to be inserted, and to redesign the schematic map of the city. A quick morphological analysis identifies the orography of the site in axonometric schemes, the fortification system consisting of the city and citadel walls and the relative towers, and the hippodamus-type urban fabric.

The intention is to provide iconic images that can convey the shape of the building at the time of its full activity (fig. 10- I2), together with the $1: 1000$ scale elaborations relating to the urban form. The present work also wants to refer to the research context inherent in the morphological study of the cities of sands, fragile realities in reference to which, as Gaetano Ginex writes: "continuing the erosion of the weak traces now almost dissolved in the sand, it is probable that they can disappear forever leaving only the memory of them" [Ginex 20 17, p. 17]. The development of an essentially archaeological environment in an architectural environment could be configured in the continuation of this study, in a more in-depth three-dimensional reconstruction of the city presented here and/or in the analysis of other religious buildings including the synagogue and the Mithraeum.

\section{Notes}

[I] A fair amount of written documentation comes from the site. The most frequent papyri and parchments are in Latin (referable to the garrison stationed in the city), in Greek (contractual type and as fragment of literary works). The literature in Semitic language is scarcer:"a liturgical parchment of the synagogue, in Hebrew, a contract for the sale of a slave in proto-Syriac and a parchment, paraphs a testament, in Babylonian Judaic Aramaic. three parchment Persian were also found" [Grassi 2007, p. 268]. The epigraphic documentation is also considerable: "the text of the epigraphs, even with the clear prevalence of Greek testify the use, not only of Latin, limited to soldiers and imperial dedications, but also of various Aramaic dialects (Palmyrene, Hatrena language, Judeo-Aramaic, Proto-Syriac), Safatic, Parthian and Middle Persian" [Grassi 2007, p. 269].

[2] "Emenso itaque itinere bidui prope civitatem venimus Duram desertam marginibus amnis impositam. In quo loco greges cervorum plures inventi sunt, quorum alii confixi missilibus, alii ponderibus illisi remorum ad satietatem omnes paverunt; pars maxima natatu assueta veloci alveo penetrato incohibili cursu evasit ad solitudines notas" [Ammianus, Rerum Gestarum, 24.I.5.]

[3] More recent excavations have been carried out, starting from 1986, within a Franco-Syrian agreement and led by P. Leriche.

[4] Regarding pre-Constantinian buildings and sources, see: F. Guidobaldi 20 I4, pp. 36 I-443.

[5] Formally, the building presented itself to the discoverers as a common home in Dura:" In character the structure is simply a typical private house of Dura, modified slightly to adapt it to religious use. The entrance is unobtrusive, an ordinary doorway leading in from street 3 at the northeast corner of the building" [Bradford Welles 1967, p. 3].

[6] Regarding the architecture of the first Christian communities, see: Brandt 2016.

[7] On the healing of the paralytic, see: Ferri 2015.

[8] Aerial and satellite surveys show how the city appears nowadays as a large Swiss cheese dotted with large holes.

[9] Text to which reference should be made for a detailed description of the building and its phases.

[I0] Plan IV e Plan V.

[I I] Plan VII.

[12] Plan VI e Plan VIII.

[I 3] Plan II.

\section{References}

Baird J.A. (2020). The Ruination of Dura-Europos. In Theoretical Roman Archaeology Journal. 3 ( I), p. 2: <https://traj.openlibhums. org/articles/10.16995/traj.42 I/> (accessed 2021, January 25).

Bisconti F. (1989). Le rappresentazioni urbane nella pittura cimiteriale romana: dalla città reale a quella ideale. In Actes du Xle Congrès International d'Archéologie Chrétienne, Roma, Città del Vaticano: Pontificio Istituto di Archeologia Cristiana, pp. I3051321 .

Bisconti F. ( 1996). Genesi e primi sviluppi dell'arte cristiana: i luoghi, i modi, i temi. In A. Donati (a cura di). Dalla terra alle genti: la diffusione del Cristianesimo nei primi secoli (Catalogo della mostra, Rimini, 31 marzo- I ${ }^{\circ}$ settembre 1996), Milano, pp. 7 I-93.

Bisconti F. (20|4). Immagini cristiane della tarda antichità. In Lezioni di Archeologia Cristiana, pp. 50 I-583.

Bisconti F. (2000a). Programmi figurativi. In E. La Rocca, E. Ensoli (a cura di). Aurea Roma dalla città pagana alla città cristiana. Roma: L'Erma di Bretschneider. 
Bisconti F. (2000b). Temi di iconografia paleocristiana. Città del Vaticano: Pontificio Istituto di Archeologia Cristiana.

Bisconti F. (20 I0). Il tesoro nascosto della Pompei d'Oriente. L'affresco della Domus Ecclesiae di Dura Europos è il più antico sul tema delle donne al sepolcro vuoto. In Osservatore Romano n. 78, 4 aprile 20 I 0, p. 4.

Bisconti F. (20 I I). Le pitture delle catacombe romane: restauri e interpretazioni. Pian di Porto:Todi Tau.

Bisconti F., Braconi M. (2012). II riuso delle immagini in età tardoantica: L'esempio del Buon Pastore dall'Abito Singolare. In Antichità Altoadriatiche 74, pp. 231 -240.

Bradford Welles C. (a cura di). (1967). The excavations at Dura-Europos conducted by Yale University and The French Academy of Inscriptions and Letters, Final Report VIII, part II. New Haven: Dura-Europos publications.

Brandt O. (2016). La croce e il capitello: le chiese paleocristiane e la monumentalità. Città del Vaticano: Pontificio Istituto di Archeologia Cristiana.

Bucolo R. (2009). La samaritana al pozzo nel cubicolo A3 della catacomba di S. Callisto tra funzione iconografica e interpretazione patristica. In Rivista di Archeologia Cristiana 85, pp. I07- 124.

Ferri G. (2015). Ecce sanus factus es, iam noli peccare. Spunti e riflessioni sull'iconografia del miracolo della guarigione del paralitico nella pittura cimiteriale cristiana delle origini. In Vetera Christianorum 52, pp. 87- 109.

Ginex G. (20/3). Città del mito: la cittadella di Aleppo. “Un progetto di rappresentazione per preservarne l'identità". In A Conte, M. Filippa (a cura di). Patrimoni e siti UNESCO. Memoria, misura e armonia. Atti del $35^{\circ}$ convegno dei docenti della rappresentazione, X Congresso UID, Matera, 24/26 ottobre 2013, pp. 483-493. Roma: Gangemi editore.

Ginex G. (2017). Nefta e le città oasi di Tamerza, Mides e Chebika. Reggio Calabria: Iriti.

Grassi F. G. (2007). L'onomastica di Dura-Europos. In Kaskal. Rivista di storia, ambienti e culture del Vicino Oriente Antico, vol. 4 pp. 267-295.

Guidobaldi F. (20|4). Architettura paleocristiana. In F. Bisconti, O. Brandt (a cura di). Lezioni di Archeologia Cristiana (Sussidi allo studio dell'Archeologia Cristiana, 27), Città del Vaticano, pp. 36I-443.

Hopkins C. (1934). The Cristian chapel at Dura-Europos. In Pontificio Istituto di Archeologia Cristiana (a cura di). Studi di antichità cristiana. Atti del III Congresso internazionale di Archeologia Cristiana. Ravenna, 25-30 settembre 1932, pp. 483-492. Roma: PIAC.

Peppard M. (2016). The World's Oldest Church. Bible, Art, and Ritual at Dura-Europos, Syria. New Haven and London: Yale University Press.

Pergola A. (20 I0). La discussa scena delle donne al sepolcro nel battistero di Dura Europos. Alle origini dell'iconografia della resurrezione di Cristo. In Rivista di Archeologia Cristiana 86, pp. 315-352.

Rostovtzeff M. ( 197 I). Città Carovaniere. Bari: Editori Laterza. [Prima ed. Caravan Cities. London: Clarendon Press, I932].

Stilo F. (2020). L'enigma del Monastero di Santa Barbara. Tra storia e rappresentazione. In A. Arena et al. (a cura di). Connettere. Un disegno per annodare e tessere. $42^{\circ}$ Convegno internazionale dei docenti delle discipline della rappresentazione, pp. $2736-2757$. Milano: Franco Angeli.

Wolfgang S. (a cura di). (1978). Ammiani Marcellini Rerum gestarum libri supersunt. Leipzig: B.G. Teubner.

\section{Authors}

Francesco Stilo, Università degli Studi Mediterranea di Reggio Calabria, francesco.stilo@unirc.it

Crystel Mamazza, Pontificio Istituto di Archeologia Cristiana, crystelmamazza3@gmail.com.

To cite this chapter. Stilo Francesco, Mamazza Crystel (2021). Architettura sacra lungo le sponde del fiume Eufrate. Dura-Europos, il primo edificio di culto cristiano/Sacred architecture along the banks of the Euphrates River. Dura Europos, the first building for Christian worship. In Arena A., Arena M. Mediati D. Raffa P. (a cura di). Connettere. Un disegno per annodare e tessere Linguaggi Distanze Tecnologie. Atti del $42^{\circ}$ Convegno Internazionale dei Docenti delle Discipline della Rappresentazione/Connecting. Drawing for weaving relationship. Languages Distances Technologies. Proceedings of the $42^{\text {th }}$ International Conference of Representation Disciplines Teachers. Milano: FrancoAngeli, pp. I I 6 I - I I 78. 